\title{
PERUBAHAN GAYA HIDUP MAHASISWI UNIVERSITAS ABDURACHMAN SALEH KOTA SITUBONDO (STUDI KASUS: PERILAKU KONSUMTIF MAHASISWI FAKULTAS EKONOMI JURUSAN MANAJEMEN ANGKATAN 2014 DALAM MENGGUNAKAN KOSMETIK BRANDED)
}

\author{
Ayuni $^{1}$, Pudjo Suharso ${ }^{1}$, Sukidin ${ }^{1}$ \\ ${ }^{1}$ Program Studi Pendidikan Ekonomi, Fakultas Keguruan dan Ilmu Pendidikan, Universitas Jember \\ e-mail: ayuni.ay1996@gmail.com
}

\begin{abstract}
Abstrak
Perilaku konsumtif merupakan tindakan seseorang dalam mengkonsumsi barang yang tidak didasarkan pada kebutuhan, melainkan hanya karena keinginan semata. Sehingga perilaku konsumtif berpengaruh terhadap gaya hidup mahasiswi yang cenderung berubah. Penelitian ini bertujuan untuk mendeskripsikan alasan serta faktor yang mempengaruhi perilaku konsumtif mahasiswi Fakultas Ekonomi Jurusan Manajemen Angkatan 2014 dalam menggunakan kosmetik branded. Penelitian ini merupakan penelitian kualitatif deskriptif. Metode pengumpulan data yang digunakan yaitu observasi, wawancara dan dokumentasi. Metode analisis data yang digunakan yaitu reduksi data, penyajian data dan verifikasi data. Hasil penelitian menunjukkan bahwa konsumsi mahasiswi Fakultas Ekonomi Jurusan Manajemen Angkatan 2014 mengalami peningkatan. Perilaku konsumtif terhadap kosmetik branded dipengaruhi oleh tujuan mahasiswi untuk menjaga image, harga diri dan pandangan mereka mengenai suatu hal. Berikut beberapa alasan serta faktor yang mempengaruhi perilaku konsumtif mahasiswi. Pertama, modernisasi yang didukung oleh perkembangan teknologi yang semakin canggih. Kedua, simbol dan status sebagai mahasiswi yang banyak dipengaruhi oleh teman sebaya. Ketiga, keinginan mahasiswi untuk mengubah gaya hidupnya dipengaruhi oleh kontrol diri yang kurang baik, mahasiswi lebih mempercayai pendapat orang lain dibandingkan dengan dirinya. Keempat, image dan pandangan diri terhadap sesuatu. Harga diri serta penilaian positif masyarakat tentang penampilan mereka yang dipengaruhi oleh citra diri sebagai seorang mahasiswi.
\end{abstract}

Kata Kunci: Gaya Hidup, Perilaku Konsumtif, Faktor yang Mempengaruhi Perilaku Konsumtif, Kosmetik, Branded

\section{PENDAHULUAN}

Penampilan cantik, modis dan modern dengan penggunaan kosmetik ternama menjadi kegiatan seharihari mahasiswi dan merupakan suatu kewajiban serta tuntutan utama untuk mendukung status mereka sebagai mahasiswi yang memiliki kedudukan tertinggi dalam bidang pendidikan. Banyak mahasiswi menggunakan kosmetik ternama di Indonesia dengan tujuan untuk menjaga image, harga diri serta mendukung penampilannya supaya sesuai dengan perkembangan zaman. Tuntutan berpenampilan modern tentunya mempengaruhi perilaku mereka dalam mengkonsumsi kosmetik yang terus meningkat. Perilaku konsumtif inilah yang mempengaruhi terhadap gaya hidup mahasiswi Fakultas Ekonomi Jurusan Manajemen Angkatan 2014 yang mengalami perubahan.

Gaya hidup merupakan sebuah ciri dunia modern, atau modernitas. Artinya siapapun yang hidup dalam masyarakat modern, akan menggunakan istilah gaya tentang hidup untuk menggambarkan tindakannya sendiri maupun orang lain. Gaya hidup merupakan pola-pola tindakan yang membedakan satu orang dengan yang lain. Mencakup sekumpulan kebiasaan, pandangan dan pola-pola respon terhadap hidup, serta terutama perlengkapan untuk hidup seperti cara berpakaian, cara kerja, pola konsumsi, bagaimana individual mengisi kesehariannya merupakan unsur-unsur yang membentuk gaya hidup (Chaney dalam suyanto, 2013:142).

Berbeda dengan mahasiswi Fakultas Ekonomi Jurusan Manajemen Angkatan 2014 yang memiliki pola pikir yang lebih modern. Pola pikir yang lebih mengutamakan penampilan cantik, modis, dan modern dengan penggunaan kosmetik ternama yang diyakini mampu menutupi segala kekurangan serta membuat penampilan mereka jauh lebih indah. Sesuai dengan apa yang dijelaskan dalam peraturan Mentri Kesehatan RI No. 445/MenKes/PerMenKes/1998 yang menyatakan bahwa kosmetik adalah kesediaan atau paduan bahan yang siap untuk digunakan pada bagian luar badan untuk membersihkan, menambah daya tarik, mengubah 
penampakan, melindungi supaya tetap dalam keadaan baik dan lain-lain. Banyak mahasiswi menggunakan kosmetik ternama di Indonesia dengan tujuan menjaga image, harga diri serta mendukung penampilannya supaya sesuai dengan perkembangan zaman. Tuntutan berpenampilan modern tentunya membuat perilaku mereka dalam mengkonsumsi kosmetik branded terus meningkat.

Mahasiswi Fakultas Ekonomi Jurusan Manajemen Angkatan 2014 Universitas Abdurachman Saleh Kota Situbondo mengalami perubahan pada gaya hidupnya. Terlihat dari penampilan mahasiswi Fakultas Ekonomi yang mewah, cantik, modis dan modern dibandingkan dengan mahasiswi fakultas lain. Sebagian besar dari mahasiswi Fakultas Ekonomi Jurusan Manajemen Angkatan 2014 sangat menyukai dunia kecantikan, terbukti dengan banyaknya mahasiswi yang selalu update tentang produk-produk kecantikan ternama dan terkenal dikalangan anak muda sekarang. Seperti merek Wardah, Purbasari, LT-Pro yang merupakan produk kosmetik ternama yang banyak digunakan oleh perempuan Indonesia. Mahasiswi senang menggunakan peralatan kosmetik ternamadan terkenal.

Penampilan merupakan hal utama dan penting dalam gaya hidup masyarakat modern. Perhatian terhadap urusan penampilan sebenarnya bukanlah hal yang baru dalam sejarah. Urusan penampilan atau presentasi diri ini sudah lama menjadi perbincangan sosiologi dan kritikus budaya. Seperti yang disampaikan oleh Erving Goffman, misalnya dalam The Presentation of Self Everyday Life (1959) yang menyatakan bahwa kehidupan sosial terutama terdiri dari penampilan teatrikal yang diritualkan, yang kemudian lebih dikenal dengan pendekatan dramaturgi (dramatugical ap-proach). Manusia seolah-olah sedang bertindak diatas sebuah panggung. Bagi Goffman, berbagai penggunaan ruang, barang-barang, bahasa tubuh, ritual, dan interaksi sosial tampil untuk memfasilitasi kehidupan sosial sehari-hari (Retno Hendraningrum, 2015).

Penampilan cantik merupakan sesuatu yang sangat penting bagi mahasiswi Fakultas Ekonomi Jurusan Manajemen Angkatan 2014 Universitas Abdurachman Saleh Kota Situbondo dalam kehidupannya. Penampilan cantik adalah sesuatu yang banyak dicita-citakan oleh seorang wanita pada umumnya. Menurut mereka cantik adalah aset terpenting, modal awal, dan faktor yang mendukung kepercayaan diri yang mereka miliki. Sehingga harus tetap dijaga dan dirawat sebagai modal awal mereka untuk bersosialisasi dan bergaul dengan orang lain.

Mahasiswi yang dikategorikan sebagai remaja memiliki karakteristik yang suka berbelanja, berdandan dan dipuji cenderung menyebabkan mereka memiliki perilaku konsumtif. Sesuai dengan pendapat Sumartono dalam Devya (2015) yang menyatakan bahwa perilaku konsumtif merupakan suatu perilaku yang tidak lagi didasarkan pada pertimbangan rasional melainkan karena adanya keinginan yang sudah mencapai taraf tidak rasional lagi. Perilaku konsumtif melekat pada seseorang bila orang tersebut membeli sesuatu di luar kebutuhan (need) atau pembelian lebih didasarkan pada faktor keinginan (want). Perilaku konsumtif mahasiswi banyak terjadi pada pengonsumsian kosmetik ternama dan terkenal dikalangan mereka, umumnya disebut dengan kosmetik branded.

Konsumsi mahasiswi Fakultas Ekonomi Jurusan Manajemen Angkatan 2014 Universitas Abdurachman Saleh Kota Situbondo terhadap kosmetik branded semakin tidak terkontrol. Hal tersebut karena adanya tuntutan penampilan yang harus sempurna. Konsumsi remaja putri terhadap suatu barang jauh lebih banyak dibandingkan dengan remaja pria, karena mahasiswi terus melakukan pembelian selagi keinginan mereka masih belum tercapai. Pernyataan tersebut diperkuat oleh penelitian yang dilakukan oleh Lina dan Rosyid (1997) tentang perilaku konsumtif berdasarkan locus of control pada remaja putri, mengamati bahwa remaja putri membelanjakan uangnya dua kali lebih banyak dari remaja pria, remaja putri dalam mengkonsumsi suatu barang yang mereka inginkan cenderung terus meningkat selama barang itu dianggap penting dan menunjang penampilan mereka. Remaja putri membelanjakan uangnya lebih banyak untuk keperluan penampilan seperti pakaian, kosmetik, aksesoris, dan sepatu. Kosmetik atau biasa disebut dengan make-up adalah kegiatan mengubah penampilan dari bentuk asli dengan bantuan bahan dan alat kosmetik. Istilah make-up lebih sering ditujukan kepada pengubahan bentuk wajah, meskipun seluruh tubuh bisa di hias.

Berdasarkan observasi awal yang dilakukan diketahui bahwa penampilan cantik, modis dan modern merupakan mimpi terbesar serta tujuan utama mereka sebagai mahasiswi. Untuk mendukung penampilan mereka supaya terlihat sempurna mereka menggunakan kosmetik terkenal dan ternama di Indonesia. Penggunaan kosmetik branded tersebut tujuannya untuk menjaga image, harga diri dan pandangan masyarakat terhadap penampilan mereka. Kosmetik branded tersebut merupakan barang penting yang harus dimiliki oleh perempuan. Diperkuat dengan penelitian yang dilakukan oleh Devya (2015) bahwa remaja melakukan suatu kegiatan membeli karena remaja memiliki karakteristik tersendiri dalam hal penampilan, berdandan, berpakaian, gaya rambut sehingga mendorong remaja untuk membelanjakan uangnya untuk keperluan tersebut. 


\section{METODE}

Penelitian ini merupakan jenis penelitian kualitatif deskriptif. Penentuan lokasi penelitian menggunakan metode purposive area. Penelitian ini dilakukan di kampus Universitas Abdurachman Saleh Kota Situbondo pada Fakultas Ekonomi Jurusan manajemen Angkatan 2014. Penelitian ini dilakukan di kampus Universitas Abdurachman Saleh Kota Situbondo pada Fakultas Ekonomi Jurusan manajemen Angkatan 2014 Jenis dan sumber data yang digunakan dalam penelitian ini yaitu data primer dan data sekunder. Metode pengumpulan data yang digunakan yaitu observasi, wawancara dan dokumentasi. Metode analisis data yang digunakan yaitu reduksi data, penyajian data dan verifikasi data.

\section{HASIL DAN PEMBAHASAN}

\section{Hasil Penelitian}

Hasil penelitian yang didapat dilapangan mengenai perubahan gaya hidup mahasiswi Universitas Abdurachman Saleh Kota Situbondo ditinjau dari perilaku konsumtif mahasiswi Fakultas Ekonomi Jurusan Manajemen Angkatan 2014 dalam menggunakan kosmetik branded:

\section{Perilaku Berkonsumsi Mahasiswi}

Mahasiswi Fakultas Ekonomi Jurusan Manajemen Angkatan 2014 umumnya memiliki suatu perilaku konsumsi yang dapat dikatakan masuk dalam kategori konsumtif. Sifat konsumtif atau boros terhadap pengonsumsian barang yang bukan menjadi kebutuhan umumnya akan terus menerus dilakukan sehingga menjadi sebuah kegiatan yang wajib terlaksana selama keinginan atau hasrat tersebut tidak terpenuhi. Hal tersebut tentunya disebabkan karena pola pandangan mereka yang juga berubah bahwasanya mereka harus menggunakan atau memiliki barang atau produk baru supaya tidak ketinggalan zaman, dianggap mampu dan modern, serta mendapat penilaian positif dari masyarakat sehingga meskipun sebenarnya barang yang mereka punya sudah ada dan pernah mereka beli. Maka tidak menutup kemungkinan mereka akan membeli barang yang memiliki fungsi dan kegunaan yang sama dengan model yang berbeda.

Banyaknya pengeluaran yang dilakukan oleh mahasiswi tergantung dari banyaknya barang yang ingin mereka beli apalagi ketika ada pengeluaran produk baru. Mereka cenderung akan merogoh kocek lebih banyak lagi utnuk membeli barang tersebut supaya tidak ketinggalan zaman untuk mempunyai barang tersebut. Padahal barang baru yang mereka beli merupakan barang yang sebenarnya sudah mereka miliki. Namun karena adanya hasrat yang sangat besar untuk memiliki barang tersebut pengonsumsianpun akan terus-menerus dilakukan.

Hal tersebut menyebabkan konsumsi mahasiswi Fakultas Ekonomi Jurusan Manajemen Angkatan 2014 Universitas Abdurachman Saleh Kota Situbondo mengalami peningkatan. Banyaknya pengeluaran yang mereka lakukan untuk sekedar mengkonsumsi barang yang mereka inginkan menyebabkan suatu perilaku konsumtif dalam diri mereka. Konsumsi mahasiswi yang mengalami peningkatan bukan dalam hal memenuhi kebutuhan, melainkan lebih kepada menuruti hasrat dalam diri serta kebiasaan-kebiasaan yang sering dilakukan. Beberapa alasan dan faktor yang menjadi unsur utama penyebab perilaku konsumtif terhadap kosmetik branded yang berpengaruh terhadap perubahan gaya hidup mahasiswi Fakultas Ekonomi Jurusan Manajemen Angkatan 2014. 1. Modernisasi

Masuknya modernisasi banyak membawa pengaruh terhadap perilaku mahasiswi yang cenderung konsumtif. Perilaku konsumtif mahasiswi yang berdampak terhadap perubahan gaya hidupnya disebabkan oleh banyaknya tren penampilan yang diadopsi dari negara lain serta zaman yang semakin berkembang yang ditandai salah satunya dengan perkembangan teknologi yang semakin canggih. Zaman yang sudah modern secara tidak langsung juga membuat pola pikir anak kuliahan zaman sekarang juga lebih modern, lebih mementingkan penampilan daripada kemampuan akademik.

Mahasiswi memerlukan segala macam bentuk barang sebagai alat untuk menunjang penampilan mahasiswi supaya lebih percaya diri dan terlihat modern. Hal tersebut tidak lepas dari apa yang namanya kosmetik. Kosmetik memiliki tren tersendiri dan terus mengalami perkembangan dikalangan anak muda dari zaman ke zaman. Untuk terlihat lebih modern terdapat banyak mahasiswi menggunakan kosmetik untuk menunjang penampilannya. Pentingnya penggunaan kosmetik hampir 100\% untuk mahasiswi zaman sekarang. Kosmetik secara tidak langsung menutup segala kekurangan yang ada pada perempuan. Kosmetik juga memberikan dampak psikologis dalam penggunaannya terhadap mahasiswi. Mereka lebih percaya diri untuk tampil didepan umum. Seperti yang disampaikan oleh DL selaku informan utama:

“kalau saya pribadi pastinya kosmetik mbk, karena hampir 90\% kalau saya sudah pakai kosmetik, 
sedikit banyak jerawat saya ketutup mbk, dan juga kalau sudah pakai kosmetik wajah kita itu ada yang beda mbk, kayak yang lebih fresh aja, kan lebih percaya diri juga sih mbk”(DL, 22 Tahun)

Perkembangan teknologi yang semakin canggih ini mempermudah gaya serta budaya luar masuk dan mempengaruhi masyarakat Indonesia terlebih mahasiswi yang dikategorikan sebagai anak muda yang mudah terpengaruh. Adanya motivasi dari artis-artis idola yang menjadikan semangat tersendiri bagi mahasiswi untuk memiliki penampilan yang sama. Pasar online atau bahasa yang sering dikatakan oleh mahasiswi adalah Online shop merupakan tempat tebaru bagi masyarakat pada umumnya untuk membeli apapun yang mereka butuhkan dan inginkan. Online Shop menyediakan barang apapun termasuk kosmetik serta barang lainnya. Dengan Online Shop masyarakat tidak perlu bersusah payah untuk mendatangi tempat penjualnya.

2. Simbol dan status

Perilaku konsumtif mahasiswi dalam menggunakan kosmetik branded yang berdampak terhadap perubahan gaya hidup mahasiswi Fakultas Ekonomi Jurusan Manajemen Angkatan 2014 disebabkan karena adanya simbol dan status. Mereka beranggapan bahwa sebagai seorang mahasiswi penampilan serta perilaku mereka harus sesuai dengan status mereka sebagai seorang mahasiswi, yang mana seorang mahasiswi memiliki kedudukan tertinggi dalam status pendidikan di mata masyarakat.

Penampilan luar yang cantik, modern, dan modis menjadi harta yang sangat berharga bagi kalangan mahasiswi pada umumnya. Apalagi jika dikaitkan dengan status sebagai seorang mahasiswi. Pelajar yang banyak dihargai dan mendapat tempat tersendiri dimata masyarakat. Jika penampilan tidak mendukung status mereka sebagai mahasiswi. Masyarakat pun cenderung akan menilai negatif terhadap penampilan mereka. Seperti yang disampaikan oleh DP:

"menurut saya penampilan menarik, cantik itu nomer satu mbk, karena jurusan saya saja jurusan ekonomi. Jurusan yang mahasiswanya akan terjun dalam dunia kerja seperti bank, perpajakan, pegadaian. Jadi penampilan sangat penting. Untuk menjadi karyawan bank, perpajakan, pegadaian kita dituntut harus punya penampilan yang menarik"'(DP, 22 Tahun)

Status dan keadaan mereka saat ini menuntut suatu adanya perubahan. Status tertinggi yang dimiliki oleh seorang pelajar dalam jenjang pendidikan yaitu sebagai seorang mahasiswi. Status mereka yang mengharuskan untuk memiliki penampilan yang lebih baik, cantik, menarik, dan modern. Memiliki penampilan yang cantik, menarik, modern dengan tujuan untuk menunjukkan dan menunjang status mereka sebagai seorang mahasiswi. Pola pikir semacam itu tentunya juga dipengaruhi karena teman bergaul mereka. Sehingga sikap meniru mulai mereka miliki setelah mengenal dan berteman dengan orang baru dan lingkungan baru.

3. Keinginan dalam diri sendiri

Perilaku konsumtif mahasiswi dalam menggunakan kosmetik branded yang berdampak terhadap perubahan gaya hidup mahasiswi Fakultas Ekonomi Jurusan Manajemen Angkatan 2014 disebabkan karena keinginan dalam diri sendiri. Keinginan mahasiswi untuk berubah dan memiliki penampilan yang lebih baik lagi. Hasrat dan keinginan yang besar dalam mencapai suatu tujuan akan mengubah pola tingkah laku masyarakat secara umum. Mereka berpikir bahwa mereka memiliki tujuan sangat penting dan harus tercapai. Hasrat dan keinginan apabila belum mampu dicapai maka orang-orang akan terus berusaha sampai pada targetnya.

Semua faktor menjadi satu-kesatuan dan saling mendukung dalam upaya mempengaruhi dan merubah suatu gaya hidup mahasiswi. Keinginan timbul karena adanya pengaruh dari luar seperti teman sebaya serta teknologi yang semakin berkembang dengan cepat. Lingkungan baru seperti kuliah dan teman yang baru membawa suatu pengaruh baru terhadap seorang mahasiswi. Mahasiswi yang masih labil dan rentan terhadap pengaruh-pengaruh luar. Kontrol yang tidak baik dalam diri akan terus membawa seseorang dalam lingkaran perilaku konsumtif. Mereka membeli karena pengaruh luar yang umumnya bukan karena kebutuhan yang dirasakan.

Anak muda cenderung lebih mempercayai orang lain daripada dirinya sendiri. Apa yang mereka lihat dan nilai berasal dari apa yang orang lain sampaikan. Jika menurut mereka penampilan si A sangat cantik dan modis apabila menggunakan pakaian serta tas yang digunakannya. Maka si B juga akan berkeyakinan bahwa apabila dia menggunakan barang yang sama dengan si A, dia juga akan memiliki penampilan yang sangat cantik dan modis seperti apa yang dia lihat pada penampilan si A. Ketika hal tersebut terus-menerus 
terjadi maka perilaku-perilaku membeli terhadap barang yang bukan menjadi kebutuhan akan terus meningkat selama keinginan tersebut belum tercapai. Seperti yang disampaikan oleh EW selaku informan utama:

"keinginan mbk, ingin tampil lebih cantik, modern, tidak kudet dan yang pasti karena ingin tampil sama seperti teman-teman"(EW, 22 Tahun)

Untuk memenuhi segala kebutuhan maupun keinginan mereka yang ingin memiliki penampilan yang jauh lebih baik, tentunya dibutuhkan modal berupa pendapatan atau pemasukan yang mereka miliki. Dibutuhkan uang yang tidak sedikit untuk mewujudkan segala keinginan mereka untuk memperbaiki segala penampilan mereka yang kurang. Jika tidak ada modal maka semuanya tidak akan terwujud. Tentunya hal itu akan terpenuhi jika terdapat adanya pemasukan, baik dari orang tua maupun dari hasil kerja sendiri.

4. Image dan pandangan diri terhadap sesuatu

Perilaku konsumtif mahasiswi dalam menggunakan kosmetik branded yang berdampak terhadap perubahan gaya hidup mahasiswi Fakultas Ekonomi Jurusan Manajemen Angkatan 2014 disebabkan karena image dan pandangan diri terhadap sesuatu. Mahasiswi Fakultas Ekonomi Jurusan Manajemen Angkatan 2014 sangat memperhatikan bagaimana komentar masyarakat mengenai penapilan mereka, sehingga mereka benar-benar menjaga diri supaya tetap terlihat baik sesuai dengan status mereka.

Kebanggaan dan kekaguman terhadap diri sendiri ketika mendapat pujian dan penilaian positif dari masyarakat apalagi orang-orang terdekat menjadi motivasi tersendiri untuk seseorang mengubah penampilannya. Ketika mahasiswi takut dinilai negatif dan digambarkan sebagai seseorang yang gagal dalam menjaga penampilan, maka rasa percaya diri mereka akan ikut menurun atau bahkan hilang. Adanya penilaian positif serta pujian dari orang-orang sangat mereka butuhkan, dengan begitu mereka akan menganggap bahwa mereka berhasil mengubah penmpilannya menjadi lebih baik. Seperti yang disampaikan oleh RJ selaku informan utama penelitian ini:

"iya sangat penting mbk, karena wanita kalau terlihat cantik, menarik pasti merasa senang dan PD saat berhadapan dengan orang banyak. Apalagi kalau seseorang yang mengatakan kita cantik kita akan merasa senang. Karena kita berhasil membuat diri kita itu lebih baik. baik untuk kita dan baik dimata orang lain"(RJ, 22 Tahun)

Ketika terdapat pandangan diri bahwa penilaian serta komentar masyarakat sangat penting untuk mereka, berpengaruh terhadap hidup mereka. Mereka akan cenderung menyesuaikan keadaan serta memperbaiki bagaimana caranya untuk mendapat nilai positif dari masyarakat. Hal tersebut tentunya akan menimbulkan suatu konsep bahwa penampilan mereka harus sempurna. Tentunya penampilan sempurna tidak lepas dengan apa yang dinamakan barang-barang branded dan ternama. Mulai dari pakaian, tas serta kosmetik yang mereka pakai. Merek terkenal akan mendukung penampilan mereka serta nama baik mereka di masyarakat, mereka akan dianggap mampu dan modern apabila segala sesuatu yang mereka pakai merupakan merek yang terkenal.

Tabel 1. Nama Merek Kosmetik Branded yang Digunakan Oleh Informan Utama

\begin{tabular}{ccc}
\hline No. & Nama & Merek \\
\hline 1. & Devica Lia & Wardah \\
\hline 2. & Tanti Kristian & Wardah, Purbasari dan Krim Turbo \\
\hline 3. & Ive Venella Y & Wardah, Make Over dan Pond's \\
\hline 4. & Rani Sofyatin H & Wardah dan Theraskin \\
\hline 5. & Dwi Evin W & Wardah \\
\hline 6. & Raodatul Jannah & Wardah \\
\hline 7. & Silvia Setya N & Wardah da LT-Pro \\
\hline 8. & Dwi Purwaningsih & Wardah dan Inez \\
\hline
\end{tabular}

Tabel diatas menunjukkan beberapa merek kosmetik ternama di Indonesia yang sering dikonsumsi oleh Mahasiswi Fakultas Ekonomi Jurusan Manajemen Angkatan 2014. Rata-rata mahasiswi Fakultas Ekonomi Jurusan Manajemen Angkatan 2014 membeli kosmetik dengan merek terkenal dan ternama. Merek kosmetik diatas merupakan kosmetik yang banyak dibeli meskipun stoknya masih ada di rumah. Beberapa kosmetik dengan jenis dan fungsi yang sama banyak mereka miliki bahkan lebih dari dua macam. Hal tersebut 
dikarenakan banyak pengeluaran maupun model baru yang berkaitan dengan merek kosmetik tersebut. Ratarata mahasiswi merogoh kocek ratusan ribu rupiah setiap membeli kosmetik tersebut. Berikut pengeluaran mahasiswi Fakultas Ekonomi Jurusan Manajemen Angkatan 2014 saat membeli kosmetik.

Tabel 2 Daftar Pengeluaran Informan Utama Penelitian Setiap Membeli Kosmetik Branded

\begin{tabular}{cll}
\hline No. & \multicolumn{1}{c}{ Nama } & \multicolumn{1}{c}{ Jumlah Pengeluaran } \\
\hline 1. & Devica Lia & Rp. 300.000 \\
\hline 2. & Tanti Kristian & Rp. 300.000-Rp. 400.000 \\
\hline 3. & Ive Venella Y & Rp. 400.000-Rp. 450.000 \\
\hline 4. & Rani Sofyatin H & Rp. 130.000-Rp. 250.000 \\
\hline 5. & Dwi Evin W & Rp. 350.000 \\
\hline 6. & Raodatul Jannah & Rp. 375.000 \\
\hline 7. & Silvia Setya N & Rp. 300.000 \\
\hline 8. & Dwi Purwaningsih & Rp. 250.000-Rp. 300.000 \\
\hline
\end{tabular}

Tabel diatas menunjukkan bahwa pengeluaran uang yang dilakukan oleh mahasiswi Fakultas Ekonomi Jurusan Manajemen Angkatan 2014 sangat beragam. Hal tersebut tentunya dipengaruhi oleh jumlah kosmetik yang mereka beli. Semakin banyak barang yang ingin mereka beli maka semakin banyak pula pengeluaran yang mereka lakukan. Rata-rata barang yang dibeli itu merupakan barang bermerek. Sehingga sekali beli mereka bisa mengeluarkan uang dengan jumlah yang lumayan banyak.

\section{Pembahasan}

Konsumsi mahasiswi Fakultas Ekonomi Jurusan Manajemen Angkatan 2014 terus mengalami peningkatan. Saat ini mereka banyak mengkonsumsi barang bukan didasarkan pada kebutuhan mereka, melainkan hanya karena keinginan untuk menjaga image, harga diri dan pandangan mereka mengenai suatu hal. Sesuai dengan pendapat yang disampaikan oleh Baudrillard dalam Martono (2014:95) mengemukakan bahwa rasionalitas konsumsi dalam sistem masyarakat konsumsi telah jauh berubah, karena saat ini masyarakat membeli barang bukan sebagai upaya untuk memenuhi kebutuhannya (needs), namun lebih sebagai pemenuhan hasrat (desire).

Mahasiswi Fakultas Ekonomi Jurusan Manajemen Angkatan 2014 banyak membeli kosmetik branded apalagi terdapat pengeluaran model baru. Kesetiaan terhadap kosmetik ternama membuat mahasiswi sering membeli kosmetik merek ternama meskipun persediaan dirumah masih ada. Beberapa kosmetik ternama seperti Wardah, LT-Pro, Inez, Purbasari, dan lain-lain merupakan kosmetik yang banyak dicari dan dibeli oleh kalangan anak muda seperti mahasiswi Fakultas Ekonomi Jurusan Manajemen Angkatan 2014. Seringnya membeli barang secara berlebih menyebabkan pengeluaran mahasiswi cukup banyak. Mereka merogoh kocek ratusan ribu rupiah setiap kali membeli. Pengeluaran yang dilakukan oleh mahasiswi sangat bervariasi dari Rp. 150.000 sampai dengan Rp. 450.000 dalam sekali beli kosmetik branded.

Konsumsi mahasiswi terhadap kosmetik branded tidak lain hanya karena untuk menjaga penampilan mereka supaya terlihat sempurna. Saat menggunakan kosmetik ternama dan terkenal mereka merasa lebih percaya diri dan bangga karena dianggap sebagai orang yang mampu dalam menyesuaikan dengan perkembangan zaman yang semakin modern. Perilaku konsumtif mahasiswi dalam menggunakan kosmetik branded berdampak terhadap gaya hidupnya yang berubah. Berikut beberapa alasan serta faktor yang mempengaruhi perilaku konsumtif mahasiswi Fakultas Ekonomi Jurusan Manajemen Angkatan 2014 dalam menggunakan kosmetik branded yang berpengaruh terhadap perubahan gaya hidup mereka.

Pertama, modernisasi yang mulai menyebar luas dan mempengaruhi pola pikir dan pandangan mahasiswi Fakultas Ekonomi Jurusan Manajemen Angkatan 2014. Tren modern dalam berpakaian, berhijab, dan menggunakan kosmetik menjadi alasan mereka mengubah penampilannya. Beragamnya style modern secara tidak langsung mulai mempengaruhi cara pandang serta pola pikir mereka untuk terus memperbaiki penampilannya. Hal lain yang menjadi penyebab karena perkembangan zaman yang semakin modern, segala sesuatu dapat diakses dengan mudah dan lancar. Budaya luar seperti cara berpakaian dan berdandan sedikit banyak mulai mempengaruhi pola pikir dan pandangan hidup mereka.

Iklan merupakan alat yang digunakan para produsen untuk menarik perhatian para konsumen terutama kalangan anak muda seperti mahasiswi untuk membeli barang yang dijual. Adanya iklan tentunya proses promosi menjadi mudah dan lebih terjangkau, media sosial menjadi wadah produsen untuk mempromosikan 
barangnya lewat iklan. Iklan mempengaruhi mahasiswi Universitas Abdurachman Saleh Kota Situbondo dengan cara menawarkan beragam produk yang ditawarkan oleh produsen. Hal tersebut berawal dari perilaku konsumsi mereka yang semakin meningkat, ketika konsumsi mengalami peningkatan, gaya hidup mereka juga mengalami berubah. Perilaku konsumtif mereka terhadap kosmetik yang bermerek juga mengubah gaya hidup mereka, gaya hidup mereka yang semakin modern dan hits mengikuti style penampilan dan budaya luar. Seperti yang disampaikan oleh Suyasa dalam Devya (2015) menyatakan bahwa iklan dapat mempengaruhi seseorang dalam perilakunya. Adanya iklan dapat menyebabkan suatu perilaku konsumtif terhadap seseorang, karena iklan merupakan suatu pesan yang menawarkan suatu produk yang ditujukan untuk khalayak umum lewat media sosial maupun elektronik.

Kedua, simbol dan status. Status sangat mempengaruhi perilaku serta pola pikir seseorang. Mahasiswi merupakan status yang tertinggi dalam fase pendidikan. Status dapat mempengaruhi dan membawa peubahan terhadap gaya hidup mahasiswi, karena mereka akan cenderung menyesuaikan dengan keadaan yang ada. Status menuntut mereka untuk memiliki penampilan yang baik dan sempurna. Status mereka sebagai mahasiswi membuat mereka ingin memiliki penampilan yang jauh lebih baik.

Style modern yang dipraktekkan oleh lingkungan baru yaitu teman sebaya secara tidak langsung teradopsi dan ditiru oleh seorang mahasiswi. Mereka menganggap bahwa teman sebaya merupakan model utama bagaimana mereka berpenampilan. Seringnya berkumpul dengan teman akan menyebabkan suatu pengimitasian dalam berperilaku. Sama halnya dengan apa yang disampaikan oleh Conger dan Papalia dalam Kansarena (2015) menjelaskan bahwa kelompok teman sebaya merupakan sumber referensi utama bagi seorang mahasiswi dalam hal persepsi dan sikap yang berkaitan dengan gaya hidup. Hal tersebut memperkuat beberapa pendapat diatas, bahwa sebagian besar gaya hidup mahasiswi baik dalam berpenampilan maupun berperilaku disebabkan karena suatu pengimitasian. Keinginan untuk tidak kalah jauh dengan teman-temannya, menyesuaikan dengan keadaan mereka sebagai mahasiswi yang modern dan berpendidikan tinggi.

Ketiga, timbulnya keinginan dalam diri sendiri. Keinginan yang tidak dapat dikontrol dengan baik akan membawa dampak negatif terhadap kehidupan. Ketika kebutuhan dikalahkan oleh keinginan yang tidak dapat dikontrol, maka seseorang akan cenderung memiliki sifat yang konsumtif dalam mengkonsumsi suatu barang. Mereka membeli tidak lagi didasarkan pada kebutuhan, melainkan keinginan yang terus menerus timbul. Keinginan yang besar cenderung akan membawa dampak bagi kehidupan seseorang, baik dampak positif maupun negatif.

Keinginan timbul karena pengaruh-pengaruh baik dari luar maupun dalam yang diyakini akan membawa pengaruh baik. Pada akhirnya menimbulkan suatu keinginan yang tidak dapat ditahan lagi. Saat keinginan seseorang untuk mendapatkan sesuatu sangat besar apapun akan dilakukan untuk mencapainya. Ketika konsumsi seseorang didasarkan atas keinginan semata, maka hal tersebut tentunya akan menyebabkan suatu perilaku konsumtif terhadap barang yang dianggap penting. Seperti halnya yang disampaikan oleh Baudrillard dalam Martono (2014:95) menjelaskan bahwa konsumsi masyarakat sekarang jauh telah berubah, mereka mengkonsumsi suatu barang hanya didasarkan pada pemenuhan hasrat (desire) bukan sebagai upaya untuk memenuhi kebutuhannya (needs).

Keempat, image dan pandangan diri terhadap sesuatu. Ketika di lingkungan masyarakat timbul bahwa pemandangan luar, gambaran luar sangat penting. Seseorang akan terus berupaya untuk menampakkan sesuatu yang sempurna. Mengupayakan untuk menjaga harga diri mereka dengan sebaik mungkin. Anggapan bahwa penilaian masyarakat terhadap mereka sangat penting dan berpengaruh dalam kehidupan mereka. Bagi mahasiswi menjaga image sangat penting untuk mereka, karena ketika image mereka jelek maka pandangan dan penilaian masyarakatpun akan terus negatif.

Penampilan mereka harus tampak cantik, menarik dan modern. Hal tersebut menimbulkan adanya penilaian positif, pujian dari masyarakat sekitar yang melihat mereka. Masyarakat akan tertarik pada seseorang yang memiliki penampilan cantik, menarik, modis, dan modern. Sehingga untuk menjaga itu semua mereka mengupayakan apapun yang dapat mendukung penampilan mereka. Hal tersebut didukung oleh pendapat Suyanto (2013:145-146) yang menyatakan bahwa salah satu karakteristik seseorang yang terperangkap dalam pusaran gaya hidup modern adalah adanya estetisasi penampilan diri. Artinya ketika gaya dan desain menjadi lebih penting, seseorang akan rela merogoh kocek puluhan juta untuk membeli barang-barang yang digunakan untuk menjaga image mereka. 


\section{PENUTUP}

\section{Kesimpulan}

Berdasarkan hasil penelitian dan pembahasan, maka dapat disimpulkan bahwa Konsumsi mahasiswi Fakultas Ekonomi Jurusan Manajemen Angkatan 2014 jauh mengalami perubahan. Hal tersebut disebabkan oleh beberapa hal, yaitu: (1) Modernisasi, tren berpenampilan serta perkembangan zaman yang semakin modern menjadi salah satu penyebab perubahan gaya hidup mahasiswi Fakultas Ekonomi Jurusan Manajemen angkatan 2014. Hal tersebut didukung oleh pesatnya perkembangan teknologi yang semakin canggih. (2) Simbol dan status, status mahasiswi sebagai pelajar yang memiliki kedudukan tertinggi dalam bidang pendidikan juga salah satu alasan perilaku konsumtif mahasiswi dalam menggunakan kosmetik branded. Didukung adanya pengaruh dari teman sebaya yang memiliki gaya hidup glamour dan modern. Sehingga mereka harus menyesuaikan keadaan dengan lingkungan baru. (3) Keinginan dalam diri sendiri. Keinginan untuk memiliki penampilan cantik, modis, dan modern memicu suatu adanya perilaku konsumtif terhadap seseorang. Mereka terus mengkonsumsi segala macam barang yang dianggap dapat menunjang penampilan mereka. (4) Image dan pandangan diri terhadap sesuatu. Penampilan baik serta penilaian seseorang memiliki pengaruh tersendiri bagi mahasiswi. Mereka sangat menjaga image untuk mendapat dan menarik perhatian serta penilaian positif dari masyarakat. Untuk menjaga image serta penampilan di depan orang banyak mereka menggunakan barang bermerek yang dianggap menjadi penunjang dan pendukung penampilannya.

\section{DAFTAR PUSTAKA}

Devya. 2015. Hubungan Citra Diri Dan Perilaku Konsumtif Pada Remaja Putri Yang Memakai Kosmetik Wajah. Jurnal Psikologi FISIP UNMUL. 3(1):117-128

Hendariningrum, Retno dan Muhammad Edy Susilo. 2008. Fashion Dan Gaya Hidup: Identitas Dan Komunikasi. Jurnal Ilmu Komunikasi Fisip UPN Yogyakarta. 6(2):25-32

Kanserina, Dias. 2015. Pengaruh Literasi Ekonomi Dan Gaya Hidup Terhadap Perilaku Konsumtif Mahasiswa Jurusan Pendidikan Ekonomi Undiksha 2015. Jurnal Jurusan Pendidikan Ekonomi Fakultas Ekonomi Dan Bisnis Universitas Pendidikan Ganesha. 5(1)

Lina dan Rosyid H.F. 1997. Psikologi Jurnal Pemikiran dan Penelitian Psikologi Nomor IV Tahun II. Kampus UI

Martono, Nanang. 2014. Sosiologi Perubahan Sosial :Perspektif klasik, Modern, Posmodern, Dan Poskolonial. Jakarta : Rajawali Pers

Suyanto, Bagong. 2013. Sosiologi Ekonomi: Kapitalisme Dan Konsumsi Di Era Masyarakat Post-Modernisme. Jakarta: Kencana Prenada Media Group.

Tranggono, Retno dkk. 2007. Buku Pegangan Ilmu Pengetahuan Kosmetik. Jakarta: Gramedia Pustaka Utama. 